\title{
Hand-held cell phone use while driving legislation and observed driver behavior among population sub-groups in the United States
}

\author{
Toni M. Rudisill ${ }^{1}$ and Motao Zhu $^{2,3^{*}}$
}

\begin{abstract}
Background: Cell phone use behaviors are known to vary across demographic sub-groups and geographic locations. This study examined whether universal hand-held calling while driving bans were associated with lower road-side observed hand-held cell phone conversations across drivers of different ages (16-24, 25-59, $\geq 60$ years), sexes, races (White, African American, or other), ruralities (suburban, rural, or urban), and regions (Northeast, Midwest, South, and West).

Methods: Data from the 2008-2013 National Occupant Protection Use Survey were merged with states' cell phone use while driving legislation. The exposure was presence of a universal hand-held cell phone ban at time of observation. Logistic regression was used to assess the odds of drivers having a hand-held cell phone conversation. Sub-groups differences were assessed using models with interaction terms.

Results: When universal hand-held cell phone bans were effective, hand-held cell phone conversations were lower across all driver demographic sub-groups and regions. Sub-group differences existed among the sexes ( $p$-value, $<0$. 0001 ) and regions ( $p$-value, 0.0003). Compared to states without universal hand-held cell phone bans, the adjusted odds ratio (aOR) of a driver hand-held phone conversation was 0.34 [95\% confidence interval (Cl): $0.28,0.41$ ] for females versus $0.47(\mathrm{Cl} 0.40,0.55)$ for males and $0.31(\mathrm{Cl} 0.25,0.38)$ for drivers in Western states compared to $0.47(\mathrm{Cl} 0.30,0.72)$ in the Northeast and $0.50(\mathrm{Cl} 0.38,0.66)$ in the South.

Conclusions: The presence of universal hand-held cell phone bans were associated lower hand-held cell phone conversations across all driver sub-groups and regions. Hand-held phone conversations were particularly lower among female drivers and those from Western states when these bans were in effect. Public health interventions concerning hand-held cell phone use while driving could reasonably target all drivers.
\end{abstract}

Keywords: Driving, Legislation, Cell phone, Epidemiology

\section{Background}

In 2015, the global revenue from cell phone sales was in excess of $\$ 400$ billion United States' (U.S.) dollars [1]. More than $90 \%$ of U.S. residents possess a cell phone subscription [2] and over $60 \%$ of these subscribers owns a

\footnotetext{
* Correspondence: Motao.Zhu@NationwideChildrens.org;

Motaozhu@nationwidechildrens.org

${ }^{2}$ The Center for Injury Research and Policy, The Research Institute at Nationwide Children's Hospital, 700 Children's Drive, RB3-WB5217, Columbus, $\mathrm{OH} 43205$, USA

${ }^{3}$ Department of Pediatrics, College of Medicine, Ohio State University, Columbus, OH 43210, USA

Full list of author information is available at the end of the article
}

smartphone [3], which enables users unfettered access to information and communicative abilities such as calling, texting, emailing, and video chat. A 2015 national survey of cell phone owners revealed that nearly $50 \%$ of respondents said they could not live without this technology [2]. Therefore, there is little controversy that many Americans are enamored with their mobile devices.

While cell phones permit users with a constant connection to their environment and social circles, they also can serve as a constant distraction. National surveys suggest that many do not refrain from using this technology even in situations that may be hazardous, such as 
driving $[4,5]$. There is a substantial body of literature that is comprised of experimental, epidemiologic, and naturalistic studies, which show cell phone use while driving (CPWD) negatively affects driving ability as it likely interferes with a driver's visual, manual, and cognitive function [6-9]. Because the behavior is prevalent $[10,11]$ and has been increasing $[11,12]$, CPWD presents an enormous challenge for traffic safety and public health. Some have suggested that this may be due to the fact that perpetual cell phone use is a social norm [13].

As part of the federal government's strategic plan to end CPWD, the U.S. Department of Transportation has actively encouraged states to pass CPWD legislation [14]. Consequently, states have ratified a myriad of CPWD laws consisting of bans on hand-held CPWD, texting while driving, and any cell phone use by young drivers (i.e. young driver all cell phone bans). As of October 2016, 14 states have enacted hand-held CPWD bans applicable to all drivers, 46 states have passed texting while driving bans for all drivers, and 37 states ban any type of cell phone use for young or inexperienced drivers (i.e. those with learner's permit or intermediate licenses) [15].

Various studies have investigated the effectiveness of CPWD laws on reducing collision claims, fatal/injurious crashes, hospitalizations, road-side observed and selfreported CPWD behavior [9]. Because this study focuses on road-side observed driver behavior, only these types of studies shall be reviewed. To the authors' knowledge, seven studies have scrutinized the effectiveness of CPWD bans on road-side observed driver behavior [16-22]. Two of these studies investigated the short and long term effects of a young driver all cell phone ban on phone usage among teenage drivers in North Carolina $[17,18]$. In the first study, teenage drivers were observed one to 2 months before and then 5 months after the law passed [17]. The second study assessed the longer-term effects of these laws by observing teenage drivers at the same high schools originally sampled, but 2 years after the law's implementation [18]. The first study found that the law had minimal short-term effects on driver phone usage [17]. In the second study, hand-held cell phone conversations occurred less overall, but the authors' attributed this to the fact that texting was likely replacing talking on hand-held cell phones [18]. In regards to driver sex, these authors noted that female teen drivers were $>60 \%$ more likely to talk on phones than males both before and after the law was passed $[17,18]$. As for hand-held bans and road-side observed driver phone usage, five studies have explored this relationship [16, 19-22]. Four studies conducted by the Insurance Institute for Highway Safety investigated the short and long term effects of driver hand-held CPWD bans in Washington, DC and several New York and Connecticut communities [19-22]. In New York, hand-held CPWD initially decreased after the ban was enacted and then rose to pre-law levels 16 months later; the findings also showed that CPWD decreased among both sexes and across various age groups of drivers (i.e. $<25,25-59$, and 60 year old drivers) $[19,20]$. In Washington, DC, driver hand-held CPWD was greatly reduced both immediately after and for a year after the ban was ratified [21, 22]. In Connecticut, driver hand-held phone use was greatly reduced both immediately after and for almost 3.5 years after the passage of the law [22]. Only one study investigated road-side observed hand-held CPWD in a nationally representative sample of drivers between 2004 and 2010 using a difference-in-difference approach [16]. It appeared that hand-held bans were associated with decreased roadside observed hand-held CPWD; this relationship was consistent among drivers aged $16-24$ and $\geq 25$ years [16].

Collectively, these studies suggest that hand-held CPWD bans likely reduce road-side observed cell phone use among drivers. However, there are still extant gaps in the literature. It is not completely clear whether these cell phone laws are associated with reduced cell phone use behavior across different sub-groups of drivers, such as different ages, sexes, races/ethnicities, or even by location, such as rurality or region. Most of these studies did not formally test for sub-group differences. National surveys show that self-reported cell phone use varies by activity (i.e. if the person is calling, texting, emailing, viewing internet/apps, etc.) and also by age, sex, race/ ethnicity, and rurality [23]. For example, texting behaviors do not differ by sex, but varies inversely with age, is less common in rural areas, and is more common among African Americans and Latinos compared to White NonHispanics [23]. National self-reported surveys of drivers reveal female drivers tend to text and have hand-held cell phone conversations less than males, and that both texting and hand-held phone conversations typically decrease as driver age increases [24]. Contrarily, road-side observed surveys of drivers from 2005 to 2014 show that females have consistently used hand-held phones to converse while driving more than males [10]. Research concerning other traffic safety laws has also shown that laws are not always equally obeyed amongst population sub-groups. It is well-established in the literature that younger drivers and males typically engage in riskier driving behaviors and receive more traffic citations, particularly when it comes to seat belt use, speeding, or driving too fast for conditions compared to females or middle-aged drivers $[25,26]$. Race and ethnicity are often varied in fatal crashes concerning alcohol, seat belt non-use, and speeding [27] or with reciving traffic citations [28]. Previous studies have also shown that rural drivers tend to speed, not wear safety belts, and run stop signs/lights more than urban drivers [29, 30].

Because of these reported differences, the objective of this study was to investigate the association between hand-held CPWD laws and road-side observed hand-held cell phone 
conversations across driver sub-groups and regions. Because texting bans and young driver all cell phone bans may also influence driver behavior, this study controlled for these other bans. Given the existing research, it was hypothesized that universal hand-held bans may be associated with lower cell phone use in some driver sub-groups and regions. Determining this information is important for the development and tailoring of future public health interventions and/or public safety campaigns regarding hand-held cell phone use while driving.

\section{Methods}

\section{Data sources}

The main data source for this analysis was the 2008-2013 National Occupant Protection Use Survey (NOPUS). Conducted by the National Highway Traffic Safety Administration (NHTSA), NOPUS is the only nationally representative road-side observed survey, which is conducted annually to assess driver and passenger safety behaviors including seat belt/child restraint use, motorcycle helmet use, and electronic device use; while data pertaining to driver cell phone use has been collected since 2000, the survey has undergone several methodological changes [31]. The survey involves a two-stage sampling design with stratified probability proportional to size; the number of primary sampling units and randomly selected observations sites vary each year [31]. Trained observers are dispatched to these sites, which are located at controlled intersections (i.e. at stop lights or stop signs) [31]. These observers assess the occupants of passenger vehicles during day light hours in June of each year [31].
In addition to the safety behaviors mentioned, occupants' sex, age, and race are collected along with information such as the location of the intersection (i.e. rural, suburban, urban), traffic flow (heavy, light), etc. While the survey is nationally representative, not all states are sampled. A figure of the states sampled in the 2008-2013 NOPUS and those with universal hand-held bans are presented in Fig. 1; a list of each states' dates when these universal hand-held bans became effective are included in the Appendix. This survey is described in more detail elsewhere [31]. The 2008-2013 NOPUS data were chosen for analysis because the survey methodologies were similar these years and many states passed cell phone legislation during this time. These data were made available and permitted for use upon request from the NHTSA's Office of Behavioral Research.

In addition to the NOPUS data, a dataset of each states' cell phone use while driving laws that were in effect from January 1, 2008 to December 31, 2013 was expended. This dataset was constructed by the study authors from several sources, including the Insurance Institute for Highway Safety and the Governor's Highway Safety Association [15, 32, 33]. Each state law that was purported to exist was researched and retrieved from each state's legislative archives, which are publically available on each individual states' legislature websites. For accuracy purposes, two individuals verified and coded these laws for variables such as enactment dates, how the law was enforced, the ages of drivers the law affected, etc. In this analysis, the term 'universal' implies that the law applies to all licensed drivers.

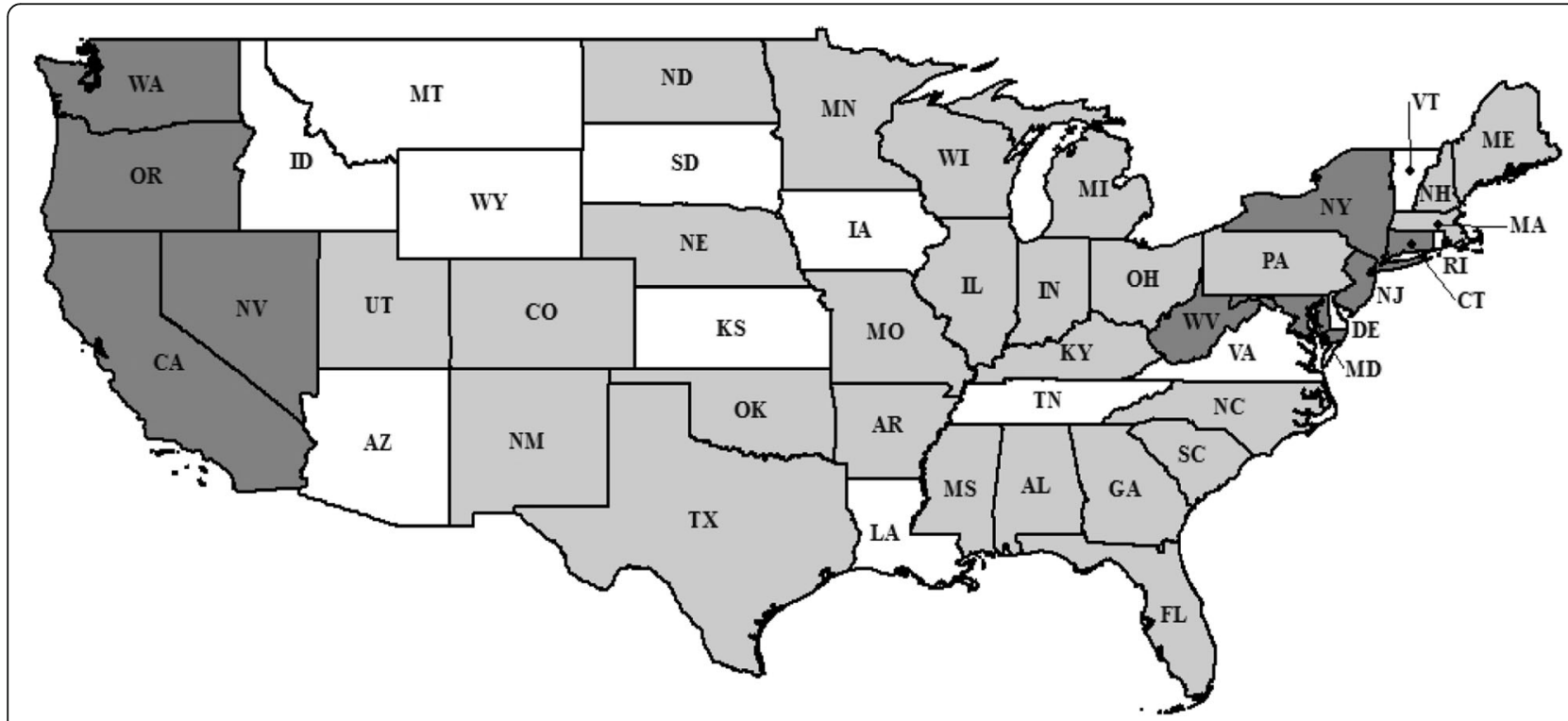

Fig. 1 Map of states included in 2008-2013 NOPUS survey. Whilst the survey is nationally representative, not all states were sampled. States shaded in white were not sampled; Alaska and Hawaii were also not sampled (not shown). States in any shade of grey were sampled. States shaded in dark grey had a universal hand-held cell phone use while driving ban implemented before or during the survey period. Illinois and New Hampshire had universal hand-held bans, which became effective after the study period (January 2014 and July 2015, respectively) 
To calculate cell phone coverage in states each year (i.e. number of cell phone subscriptions per 100 residents), the number of cell phone subscriptions per state per year were obtained from the Federal Communications Commissions' Local Telephone Competition reports [34]. Population estimates per state by year were obtained from the U.S. Census Bureau [35]. These data are all publically available and can be obtained from the Federal Communication Commission and U.S. Census Bureau's webpages.

\section{Study population and variables}

Hand-held CPWD bans mainly do not permit drivers to make hand-held phone calls and converse on hand-held devices. The primary dependent variable of this analysis, which was dichotomous, was whether or not the observed driver was engaged in a hand-held cell phone conversation while driving. In NOPUS, roadside observers categorize drivers' CPWD into 4 categories after $\sim 10 \mathrm{~s}$ of observation: 1) driver was not using a cell phone, 2) driver was holding a hand-held cell phone to their ear and conversing, 3) driver was manipulating a hand-held device, or 4) driver was using a hands-free device [31]. Drivers holding hand-held cell phones to their ear and conversing were considered to be engaged in a hand-held cell phone conversation. Drivers who were not using hand-held cell phones or who were using hands free devices were considered to not be engaged in a hand-held cell phone conversation. Drivers manipulating hand-held devices were not included in order to minimize bias; it is virtually impossible from a road-side observation site to determine if a driver was text messaging, using the internet, etc. versus dialing a phone number or terminating a cell phone call. Also, hand-held devices in NOPUS can include electronic devices which may not always be a cell phone [31]. Throughout this manuscript, the term 'hand-held cell phone use' implies a driver was having a hand-held cell phone conversation.

The primary independent variable was dichotomized as to whether or not the state where the driver was observed had a universal hand-held cell phone ban in effect at time of observation. Other predictor variables, which were noted by roadside observers, included drivers' age $(<25$, $25-60, \geq 70$ years of age), sex (male or female), race (White, African American, or other), location of observation (urban, suburban, or rural area), whether driver was wearing a seat belt (yes or no), and vehicle type (passenger car, pickup truck, van/sport utility vehicle). These categories, especially driver age, are somewhat broad because observers must categorize vehicle occupants from the roadside; broad categories minimize misclassification. The state where the observation took place was also categorized into geographic location (i.e. whether the state was in the Northeast, Midwest, West, or South); this was based on the U.S. Census region classification. The number of cell phone subscriptions per 100 residents was calculated by taking the number of subscriptions in each state divided by the states' population and multiplied by 100 for each year. Year of driver observation was also included. Because other CPWD laws, such as universal texting bans or young driver all cell phone bans, may confound the relationship between hand-held CPWD and the presence of a hand-held ban, these laws were also separately taken into account. These laws were both dichotomized into whether or not a state had these bans at time of driver observation. Two states, Mississippi and Missouri, had texting bans during this time period that were not universal. These bans applied only to drivers under 21 years of age. These bans were also factored into the analysis as a dichotomous variable (i.e. present or absent at time of driver observation) called 'non-universal texting laws' as their presence may also have confounded the relationship between hand-held CPWD and a hand-held cell phone ban.

\section{Statistical analyses}

The number of replicate weights differed for each year of the NOPUS data. In order to combine the 2008-2013 NOPUS data for analysis, pseudo strata and clusters were first created from the primary sampling units; the Taylor series approximation method was used to compute standard errors [36]. In order to determine whether hand-held cell phone bans were associated with hand-held cell phone use while driving, both crude and adjusted odds ratios were generated via logistic regression, which also accounted for the complex survey design of NOPUS (i.e. clusters and strata). Separate models were run for age, sex, race, location, and region. Models, which contained an interaction term, were run to assess for differences amongst the subgroups and hand-held ban. Adjusted models accounted for survey year, sex, race, rurality, seatbelt use, vehicle type, presence of universal texting ban, presence of young driver all cell phone ban, presence of non-universal texting laws, and the number of cell phone subscriptions per 100 residents. All analyses were run in SAS version 9.4 with $\alpha=0.05$. The map of states, which shows the states whom were sampled in the 2008-2013 NOPUS, was created using ArcMap version 10.3.

\section{Results}

Of the 263,673 drivers included in this analysis, 5.1\% $(n=13,564)$ were talking on a hand-held phone at time of observation (Table 1). The majority of drivers were judged to be between 25 and 69 years of age $(81.8 \%)$, male (58.6\%), and of White race (81.4\%). Most drivers were observed in suburban locations $(57.1 \%)$ and were wearing safety belts (85.4\%). Drivers having hand-held phone conversations tended to be younger, female, African American, and from Southern states compared to those not engaging in cell phone conversations. Over $72 \%$ of the drivers were from states where a hand-held ban was not present at time of 
Table 1 Characteristics of the roadside-observed drivers by hand-held phone status in 2008-2013 National Occupant Protection Use Survey ${ }^{a, b}$

\begin{tabular}{|c|c|c|c|c|c|c|}
\hline \multirow[b]{2}{*}{ Characteristic } & \multicolumn{2}{|c|}{$\begin{array}{l}\text { Driver not holding phone to ear or driver } \\
\text { was using a head set }(N=250,109)\end{array}$} & \multicolumn{2}{|c|}{$\begin{array}{l}\text { Driver holding phone to ears } \\
(N=13,564)\end{array}$} & \multicolumn{2}{|c|}{ Total $(N=263,673)$} \\
\hline & N & $(\%)^{\mathrm{b}}$ & N & (\%) & $N$ & (\%) \\
\hline \multicolumn{7}{|l|}{ Age (years) } \\
\hline $16-24$ & 29,799 & $(11.7)$ & 2289 & (16.5) & 32,088 & (12.0) \\
\hline $25-69$ & 204,214 & $(81.8)$ & 11,088 & (82.1) & 215,302 & (81.8) \\
\hline$>70$ & 16,096 & $(6.5)$ & 187 & (1.4) & 16,283 & $(6.2)$ \\
\hline \multicolumn{7}{|l|}{ Sex } \\
\hline Male & 146,201 & $(59.2)$ & 6383 & $(47.6)$ & 152,584 & (58.6) \\
\hline Female & 103,908 & $(40.8)$ & 7181 & (52.4) & 111,089 & (41.4) \\
\hline \multicolumn{7}{|l|}{ Race } \\
\hline White & 202,036 & $(81.5)$ & 10,777 & (80.5) & 212,813 & $(81.4)$ \\
\hline Black & 22,361 & (8.3) & 1673 & (11.4) & 24,034 & (8.4) \\
\hline Other & 25,712 & $(10.3)$ & 1114 & (8.1) & 26,826 & $(10.2)$ \\
\hline \multicolumn{7}{|l|}{ Location } \\
\hline Urban & 42,447 & $(16.7)$ & 2443 & (17.6) & 44,890 & $(16.8)$ \\
\hline Suburban & 148,174 & $(57.0)$ & 8205 & $(59.9)$ & 156,379 & (57.1) \\
\hline Rural & 59,488 & $(26.3)$ & 2916 & (22.5) & 62,404 & (26.1) \\
\hline \multicolumn{7}{|l|}{ Geographic region } \\
\hline Northeast & 63,736 & (21.3) & 2873 & (16.6) & 66,609 & (21.1) \\
\hline Midwest & 57,188 & $(23.1)$ & 3165 & (22.5) & 60,353 & (23.1) \\
\hline South & 66,420 & $(28.5)$ & 4708 & (37.1) & 71,128 & (28.9) \\
\hline West & 62,765 & $(27.0)$ & 2818 & (23.8) & 65,583 & (26.9) \\
\hline \multicolumn{7}{|l|}{ Seatbelt use } \\
\hline Yes & 214,358 & (85.6) & 11,059 & $(81.6)$ & 225,417 & $(85.4)$ \\
\hline No & 35,751 & $(14.4)$ & 2505 & $(18.4)$ & 38,256 & $(14.6)$ \\
\hline \multicolumn{7}{|l|}{ Vehicle type } \\
\hline Passenger car & 127,209 & (49.6) & 6405 & $(45.5)$ & 133,614 & $(49.4)$ \\
\hline Pick-up truck & 41,094 & $(17.0)$ & 2237 & $(17.3)$ & 43,331 & $(17.0)$ \\
\hline Van \& SUV & 81,806 & (33.4) & 4922 & $(37.2)$ & 86,728 & (33.6) \\
\hline Cell phone subscriptions per 100 residents $^{c}$ & 89 & & 88 & & 89 & \\
\hline \multicolumn{7}{|l|}{ Hand-held phone ban } \\
\hline Yes & 77,546 & $(28.3)$ & 2132 & $(14.5)$ & 79,678 & (27.6) \\
\hline No & 172,563 & $(71.7)$ & 11,432 & $(85.5)$ & 183,995 & (72.4) \\
\hline \multicolumn{7}{|l|}{ Universal texting ban } \\
\hline Yes & 124,598 & $(50.8)$ & 5310 & $(43.4)$ & 129,908 & $(50.4)$ \\
\hline No & 125,511 & $(49.2)$ & 8254 & (56.6) & 133,765 & (49.6) \\
\hline \multicolumn{7}{|l|}{ Young driver all cell phone ban } \\
\hline Yes & 130,264 & $(55.4)$ & 6117 & $(51.0)$ & 136,381 & $(55.2)$ \\
\hline No & 119,845 & $(44.6)$ & 7447 & $(49.0)$ & 127,292 & $(44.8)$ \\
\hline \multicolumn{7}{|l|}{ Other texting bans } \\
\hline Yes & 3281 & (1.7) & 225 & (1.5) & 3506 & (1.7) \\
\hline No & 246,828 & (98.3) & 13,339 & (98.5) & 260,167 & (98.3) \\
\hline
\end{tabular}

percentages may not add up to $100 \%$ due to rounding

bercentage is based on the weighted frequency

the average number of cell phone subscribers per 100 residents 
observation. A list of states and their hand-held legislations' effective dates are listed in Appendix, Table 6. Nearly half of all observed drivers were from states where universal texting bans and young driver bans were instituted at time of observation (50.4\% and $55.2 \%$, respectively).

While drivers aged 16-24 years talked on hand-held devices more than other age groups regardless of handheld ban existence, hand-held CPWD bans were associated with lower hand-held phone conversations across all age groups (Table 2).

In regards to drivers' sex, sub-group differences were seen (Table 3). Females talked on hand-held phones more than males irrespective of whether a hand-held ban was in existence. Although, hand-held CPWD bans were associated with lower hand-held phone conversations for both sexes. Hand-held phone conversations were particularly lower among women drivers when these bans were present.

In reference to drivers' race, no sub-group differences were noted $(p=0.3036)$. While African American drivers used cell phones more than other racial groups, these bans were associated with lower roadside observed cell phone use for all racial groups (Table 4).

As for driver location and region, hand-held CPWD bans were equally associated with lower hand-held cell phone conversations across rural, suburban, and urban locations ( $p=0.9290$; table not shown). While hand-held cell phone bans were associated with lower driver cell phone use in all regions (Table 5), they were particularly lower in Western states $(p=0.0003)$. Drivers in Western states with hand-held bans were associated with 69\% lower cell phone use while driving compared to $53 \%$ and $50 \%$ lower use in the Northeast and South, respectively.

\section{Discussion}

The findings of this analysis show that hand-held cell phone use while driving bans were associated with lower road-side observed hand-held cell phone conversations amongst drivers regardless of age, sex, race, location, and region. Although, when these bans were in effect, the occurrence of cell phone conversations were particularly lower amongst female drivers and drivers in Western states. While future interventional or educational efforts could be focused on all drivers, younger drivers, females, and African Americans engaged in hand-held cell phone conversations more than other groups and may benefit from directed efforts.

Other studies utilizing road-side observed data have also shown that universal hand-held CPWD bans were associated with lower occurrences of hand-held cell phone conversations amongst drivers. Studies by the Insurance Institute of Highway Safety have shown that after handheld CPWD bans were passed in New York, the District of Columbia, and Connecticut, driver cell phone use rates immediately dropped $47 \%, 41 \%$, and $76 \%$, respectively [19-22]. The study conducted in New York showed that when the data were stratified, there was $\sim 50 \%$ reduction in phone usage across both sexes and for drivers $<25$ and $25-$ 59 years after the law was passed [19]. Another study by Cheng showed that driver cell phone use rates were $45 \%$ and $40 \%$ less, respectively, for $16-24$ and $25+$ year old drivers in states with hand-held CPWD bans [16]. The findings of this study showed that drivers in states with hand-held CPWD bans were observed conversing 50\% less compared to states without bans across most of the demographic groups. Additionally, other studies have also suggested that road side observed cell phone

Table 2 The association between driver hand-held cell phone conversations and state legislation stratified by age group

\begin{tabular}{|c|c|c|c|c|c|c|c|}
\hline \multirow{2}{*}{$\begin{array}{l}\text { Characteristic } \\
\text { Hand-held phone ban in } \\
16-24 \text { year old drivers }\end{array}$} & \multirow[t]{2}{*}{ Total $\mathrm{N}^{\mathrm{a}}$} & \multirow[t]{2}{*}{$\begin{array}{l}\text { Percent of drivers holding } \\
\text { phone to earb }\end{array}$} & \multicolumn{2}{|c|}{$\begin{array}{l}\text { Crude Odds Ratio } \\
\text { ( } 95 \% \text { Confidence Limit) }^{c}\end{array}$} & \multicolumn{2}{|c|}{$\begin{array}{l}\text { Adjusted Odds Ratio } \\
\text { (95\% Confidence Limit) }^{c}\end{array}$} & \multirow{2}{*}{$\frac{P \text {-value }^{\mathrm{d}}}{0.7011}$} \\
\hline & & & & & & & \\
\hline No & 21,699 & 8.6 & 1.00 & (Referent) & 1.00 & (Referent) & \\
\hline Yes & 10,389 & 4.0 & 0.42 & $(0.34,0.51)$ & 0.43 & $(0.33,0.55)$ & \\
\hline \multicolumn{8}{|l|}{$\begin{array}{l}\text { Hand-held phone ban in } \\
25-69 \text { year old drivers }\end{array}$} \\
\hline No & 150,269 & 6.3 & 1.00 & (Referent) & 1.00 & (Referent) & \\
\hline Yes & 65,033 & 2.6 & 0.42 & $(0.36,0.48)$ & 0.39 & $(0.33,0.46)$ & \\
\hline \multicolumn{8}{|l|}{$\begin{array}{l}\text { Hand-held phone ban in } \\
>70 \text { year old drivers }\end{array}$} \\
\hline No & 12,027 & 1.4 & 1.00 & (Referent) & 1.00 & (Referent) & \\
\hline Yes & 4256 & 0.4 & 0.67 & $(0.23,1.93)$ & 0.64 & $(0.24,1.68)$ & \\
\hline
\end{tabular}

${ }^{a}$ The total number of drivers with the specified characteristic by presence/absence of hand-held cell phone use while driving legislation

${ }^{b}$ Percentage of drivers who were observed engaging in hand-held cell phone conversations by presence/absence of hand-held cell phone use while driving legislation 'All crude and adjusted odds ratios were calculated using logistic regression for complex surveys; adjusted models controlled for year, sex, race, urbanicity of location, seatbelt use, vehicle type, presence of universal texting ban (binary), presence of young driver all cell phone ban (binary), non-universal texting while driving law (binary), and the number of cell phone subscriptions per 100 residents

${ }^{\mathrm{d}}$ The $p$-value presented is from the interaction term which assessed the relationship between the sub-group and hand-held CPWD ban 
Table 3 The association between driver hand-held cell phone conversations and state legislation stratified by sex

\begin{tabular}{|c|c|c|c|c|c|c|c|}
\hline \multirow{2}{*}{$\begin{array}{l}\text { Characteristic } \\
\text { Hand-held phone ban in male drivers }\end{array}$} & \multirow[t]{2}{*}{ Total $N^{a}$} & \multirow[t]{2}{*}{$\begin{array}{l}\text { Percent of drivers holding } \\
\text { phone to ear }{ }^{b}\end{array}$} & \multicolumn{2}{|c|}{$\begin{array}{l}\text { Crude Odds Ratio } \\
\text { ( } 95 \% \text { Confidence Limit) }^{c}\end{array}$} & \multicolumn{2}{|c|}{$\begin{array}{l}\text { Adjusted Odds Ratio } \\
\left(^{95 \% \text { Confidence Limit) }}{ }^{c}\right.\end{array}$} & \multirow[t]{2}{*}{$P$-value ${ }^{\mathrm{d}}$} \\
\hline & & & & & & & \\
\hline No & 106,969 & 4.9 & 1.00 & (Referent) & 1.00 & (Referent) & \\
\hline Yes & 45,615 & 2.4 & 0.50 & $(0.43,0.58)$ & 0.47 & $(0.40,0.55)$ & \\
\hline \multicolumn{8}{|l|}{ Hand-held phone ban in female drivers } \\
\hline No & 77,026 & 8.0 & 1.00 & (Referent) & 1.00 & (Referent) & \\
\hline Yes & 34,063 & 3.0 & 0.36 & $(0.31,0.43)$ & 0.34 & $(0.28,0.41)$ & \\
\hline
\end{tabular}

${ }^{a}$ The total number of drivers with the specified characteristic by presence/absence of hand-held cell phone use while driving legislation

${ }^{b}$ Percentage of drivers who were observed engaging in hand-held cell phone conversations by presence/absence of hand-held cell phone use while driving legislation

'All crude and adjusted odds ratios were calculated using logistic regression for complex surveys; adjusted models controlled for year, age, race, urbanicity of location, seatbelt use, vehicle type, presence of universal texting ban (binary), presence of young driver all cell phone ban (binary), nonuniversal texting while driving law (binary), and the number of cell phone subscriptions per 100 residents

${ }^{d}$ The $p$-value presented is from the interaction term which assessed the relationship between the sub-group and hand-held CPWD ban

conversations were higher in females and younger drivers $[17,18,20-22]$, which was also seen in this analysis.

There may be a potential explanation as to why handheld CPWD laws were associated with lower occurrences of cell phone conversation across most drivers. As evident by the number of Americans who own cell phones and engage in its various forms of communication (i.e. texting, calling, email, video chatting, etc.), cell phones are part of the current culture [13]. Recent surveys have shown that this technology is widely accepted and frequently used across all ages, sexes, races, etc. [2,3]. National surveys show that most drivers, irrespective of demographics, acknowledge these behaviors are a threat to their personal safety and disapprove of others engaging in this technology while driving [4]. In a 2014 national survey of drivers, nearly $70 \%$ of those surveyed supported bans on handheld CPWD and $>90 \%$ supported texting while driving legislation [4]. It is possible that this widespread use of this technology, self-awareness of the consequences, and support of legislation may have discouraged the behavior across the populous.

There are also possible explanations why cell phone conversations were particularly lower among female drivers and those from Western states when hand-held bans were effective. Several studies have investigated how gender/sex, and age relate to an individuals' abatement of traffic safety laws; these studies have shown that females typically abide by traffic laws that are safetydriven more than males [37-39]. While females typically drive less than males across the age span and spend less time 'at risk', women also do typically receive traffic citations less than men, which may suggest that females are more compliant $[25,26]$. Studies of high-visibility enforcement of cell phone use while driving laws have shown in certain areas that women drivers will obey the restrictions more than males [40, 41].

As for the regional differences, most of the universal hand-held cell phone use while driving bans have been

Table 4 The association between driver hand-held cell phone conversations and state legislation stratified by race

\begin{tabular}{|c|c|c|c|c|c|c|c|}
\hline \multirow{2}{*}{$\begin{array}{l}\text { Characteristic } \\
\text { Hand-held phone ban in } \\
\text { White drivers }\end{array}$} & \multirow[t]{2}{*}{ Total Na } & \multirow[t]{2}{*}{$\begin{array}{l}\text { Percent of drivers holding } \\
\text { phone to ear }{ }^{b}\end{array}$} & \multicolumn{2}{|c|}{$\begin{array}{l}\text { Crude Odds Ratio } \\
\left(^{95 \% \text { Confidence Limit) }}\right.\end{array}$} & \multicolumn{2}{|c|}{$\begin{array}{l}\text { Adjusted Odds Ratio } \\
\text { (95\% Confidence Limit) }^{c}\end{array}$} & \multirow{2}{*}{$\frac{P \text {-value }}{\text { d }}$} \\
\hline & & & & & & & \\
\hline No & 153,950 & 6.0 & 1.00 & (Referent) & 1.00 & (Referent) & \\
\hline Yes & 58,863 & 2.6 & 0.43 & $(0.37,0.50)$ & 0.37 & $(0.32,0.45)$ & \\
\hline \multicolumn{8}{|l|}{$\begin{array}{l}\text { Hand-held phone ban in } \\
\text { African American drivers }\end{array}$} \\
\hline No & 18,334 & 8.0 & 1.00 & (Referent) & 1.00 & (Referent) & \\
\hline Yes & 5700 & 3.7 & 0.53 & $(0.40,0.69)$ & 0.62 & $(0.45,0.87)$ & \\
\hline \multicolumn{8}{|l|}{$\begin{array}{l}\text { Hand-held phone ban in } \\
\text { Other drivers }\end{array}$} \\
\hline No & 11,711 & 6.4 & 1.00 & (Referent) & 1.00 & (Referent) & \\
\hline Yes & 15,115 & 2.4 & 0.38 & $(0.29,0.51)$ & 0.43 & $(0.30,0.60)$ & \\
\hline
\end{tabular}

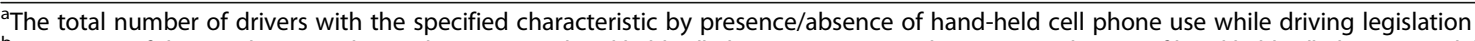
${ }^{\mathrm{b}}$ Percentage of drivers who were observed engaging in hand-held cell phone conversations by presence/absence of hand-held cell phone use while driving legislation 'All crude and adjusted odds ratios were calculated using logistic regression for complex surveys; adjusted models controlled for year, sex, age, urbanicity of location, seatbelt use, vehicle type, presence of universal texting ban (binary), presence of young driver all cell phone ban (binary), non-universal texting while driving law (binary), and the number of cell phone subscriptions per 100 residents

${ }^{\mathrm{d}}$ The $p$-value presented is from the interaction term which assessed the relationship between the sub-group and hand-held CPWD ban 
Table 5 The association between driver hand-held cell phone conversations and state legislation stratified by geographic region

\begin{tabular}{|c|c|c|c|c|c|c|c|}
\hline $\begin{array}{l}\text { Characteristic } \\
\text { Hand-held phone ban in Northeast drivers }\end{array}$ & Total Na & $\begin{array}{l}\text { Percent of drivers holding } \\
\text { phone to ear }\end{array}$ & \multicolumn{2}{|c|}{$\begin{array}{l}\text { Crude Odds Ratio } \\
\left(^{95 \%} \text { Confidence Limit) }\right.\end{array}$} & \multicolumn{2}{|c|}{$\begin{array}{l}\text { Adjusted Odds Ratio } \\
\left(^{(95 \% \text { Confidence Limit) }}{ }^{c}\right.\end{array}$} & $\begin{array}{c}P \text {-value } \\
0.0003\end{array}$ \\
\hline No & 35,126 & 5.9 & 1.00 & (Referent) & 1.00 & (Referent) & \\
\hline Yes & 31,483 & 2.6 & 0.53 & $(0.39,0.73)$ & 0.47 & $(0.30,0.72)$ & \\
\hline \multicolumn{8}{|l|}{ Hand-held phone ban in Midwestern drivers } \\
\hline No & 60,353 & 5.2 & 1.00 & (Referent) & 1.00 & (Referent) & \\
\hline Yes & N/A & N/A & N/A & N/A & N/A & N/A & \\
\hline \multicolumn{8}{|l|}{ Hand-held phone ban in Southern drivers } \\
\hline No & 62,644 & 7.0 & 1.00 & (Referent) & 1.00 & (Referent) & \\
\hline Yes & 8484 & 3.7 & 0.54 & $(0.44,0.64)$ & 0.50 & $(0.38,0.66)$ & \\
\hline \multicolumn{8}{|l|}{ Hand-held phone ban in Western drivers } \\
\hline No & 25,872 & 7.0 & 1.00 & (Referent) & 1.00 & (Referent) & \\
\hline Yes & 39,711 & 2.5 & 0.32 & $(0.26,0.39)$ & 0.31 & $(0.25,0.38)$ & \\
\hline
\end{tabular}

Abbreviations: N/A not applicable; no state had a hand-held cell phone use while driving ban in this region effective during the study period

${ }^{a}$ The total number of drivers with the specified characteristic by presence/absence of hand-held cell phone use while driving legislation

${ }^{b}$ Percentage of drivers who were observed engaging in hand-held cell phone conversations by presence/absence of hand-held cell phone use while driving legislation

'All crude and adjusted odds ratios were calculated using logistic regression for complex surveys; adjusted models controlled for year, age, sex, race, urbanicity of location, seatbelt use, vehicle type, presence of universal texting ban (binary), presence of young driver all cell phone ban (binary), non-universal texting while driving law (binary), and the number of cell phone subscriptions per 100 residents

${ }^{\mathrm{d}}$ The $p$-value presented is from the interaction term which assessed the relationship between the sub-group and hand-held CPWD ban

instituted on the east and west the coasts of the U.S. during this study period (Fig. 1). It is possible that Western states may have lower occurrences of hand-held phone conversations after the enactment of hand-held cell phone bans because these states have similar legislation. Compared to the Northeast, a larger, more contiguous area is covered by the Western states' hand-held bans. In the Northeast, states are smaller and many may commute between states that may have different laws and thus permit different behaviors. It is also possible that enforcement is higher in Western states, though this is unknown.

\section{Limitations}

One of the strengths of this study is that it utilized a nationally representative sample of road-side observed drivers to assess the association between hand-held phone conversations and universal hand-held cell phone use while driving bans, which are effective in a limited number of states. This study also controlled for other cell phone use while driving bans, such as texting and young driver all cell phone bans, which may have confounded this relationship. Despite these strengths, this study has several inherent limitations. First, the road-side observations were likely imperfect and observers may have misclassified some drivers' ages, sex, or races. However, these observers were trained and drivers were categorized into broad groups; systematic differences are unlikely between states with and without legislation. Second, while the survey was nationally representative, not all states were sampled. For example, Delaware, Hawaii, Vermont, and the District of Columbia all have hand-held bans, but were not sampled. Additionally, New Hampshire and Illinois were sampled, but had bans effective after the study period. Third, these observations occurred at controlled intersections where drivers may have been more inclined to make a call when stopped. Fourth, these observations only occurred during day light hours. Based on other traffic safety law research, it is likely that night time and day time driving behaviors differ [42, 43]. Therefore, these findings may not generalizable to nighttime observations. Fifth, this study did not control for the level of enforcement or drivers' exposure to media/educational campaigns regarding distracted driving, as this was virtually impossible; these activities may have influenced certain drivers' behaviors and not the laws themselves. Although, enforcement of cell phone use while driving laws appears low [44] and nearly all states spend money on distracted driving campaigns and driver education [45]. Lastly, it cannot be inferred that hand-held cell phone use while driving bans caused drivers to converse less on their cell phones. These findings are clearly associative.

\section{Conclusions}

The findings of this analysis suggest that universal handheld cell phone use while driving bans were associated with markedly lower hand-held cell phone conversations across all drivers, including those of different ages, sexes, races, and geographic locations. However, sub-groups differences were seen by sex and by region. As road-side observed cell phone use was higher overall among females, younger age groups, and African American drivers, these groups may benefit from directed interventional efforts. 


\section{Appendix}

Table 6 Effective dates and U.S. Census region of states sampled in the 2008-2013 National Occupant Protection Use Survey, United States

\begin{tabular}{|c|c|c|}
\hline State & $\begin{array}{l}\text { Effective dates of universal } \\
\text { hand-held cell phone use } \\
\text { while driving bans }\end{array}$ & U.S Census Region \\
\hline Alabama & NA & South \\
\hline Arkansas & NA & South \\
\hline California & 07/01/08 & West \\
\hline Colorado & NA & West \\
\hline Connecticut & 10/01/05 & Northeast \\
\hline Florida & NA & South \\
\hline Georgia & NA & South \\
\hline Illinois $^{a}$ & NA & Midwest \\
\hline Indiana & NA & Midwest \\
\hline Kentucky & NA & South \\
\hline Maine & NA & Northeast \\
\hline Maryland & $10 / 01 / 10$ & South \\
\hline Massachusetts & NA & Northeast \\
\hline Michigan & NA & Midwest \\
\hline Minnesota & NA & Midwest \\
\hline Mississippi & NA & South \\
\hline Missouri & NA & Midwest \\
\hline North Carolina & NA & South \\
\hline North Dakota & NA & Midwest \\
\hline Nebraska & NA & Midwest \\
\hline Nevada & $01 / 01 / 12$ & West \\
\hline New Hampshire ${ }^{a}$ & NA & Northeast \\
\hline New Jersey & 07/01/04 & Northeast \\
\hline New Mexico & NA & West \\
\hline New York & 11/01/01 & Northeast \\
\hline Ohio & NA & Midwest \\
\hline Oklahoma & NA & South \\
\hline Oregon & 01/01/10 & West \\
\hline Pennsylvania & NA & Northeast \\
\hline South Carolina & NA & South \\
\hline Texas & NA & South \\
\hline Utah & NA & West \\
\hline Washington & 07/01/08 & West \\
\hline West Virginia & 07/01/12 & South \\
\hline Wisconsin & NA & Midwest \\
\hline
\end{tabular}

Abbreviations: NA not applicable; no universal hand-held ban exists

a: Illinois and New Hampshire implemented hand-held cell phone bans after 2013

\section{Abbreviations}

CPWD: Cell phone use while driving; NHTSA: National Highway Traffic Safety Administration; NOPUS: National Occupant Protection Use Survey: US $=$ United States

\section{Acknowledgements}

Not applicable.

\section{Funding}

TMR and MZ received support from National Institutes of Health grants R01HD074594, R21HD085122, and R01AG050581; and Centers for Disease Control and Prevention grant R49 CE002109. The funding agencies had no role in the design of the study, collection, analysis, or interpretation of the results, or in the writing of this manuscript.

\section{Availability of data and materials}

The data that support the findings of this study are available upon request from the National Highway Traffic Safety Administration's Office of Behaviora Research. Datasets pertaining to legislation, population estimates, and cell phone coverage may be obtained from the Corresponding Author upon reasonable request.

\section{Authors' contributions}

MZ conceived the study and obtained the data. TMR processed the data, performed the analysis, and drafted the manuscript. MZ provided technical support and contributed to the intellectual content of the manuscript. TMR and MZ had full access to all the data in the study and take responsibility for the integrity of the data and the accuracy of the data analysis. Both authors contributed to the manuscript preparation and approved the final version.

\section{Competing interests}

The authors declare that they have no competing interests.

Consent for publication

Not applicable.

Ethics approval and consent to participate

Not applicable.

\section{Publisher's Note}

Springer Nature remains neutral with regard to jurisdictional claims in published maps and institutional affiliations.

\section{Author details}

${ }^{1}$ Injury Control Research Center, West Virginia University, PO BOX 9151, Morgantown, West Virginia 26506, USA. ${ }^{2}$ The Center for Injury Research and Policy, The Research Institute at Nationwide Children's Hospital, 700 Children's Drive, RB3-WB5217, Columbus, OH 43205, USA. ${ }^{3}$ Department of Pediatrics, College of Medicine, Ohio State University, Columbus, OH 43210, USA.

Received: 13 October 2016 Accepted: 7 May 2017

Published online: 12 May 2017

\section{References}

1. Statista. Global revenue from smartphone sales from 2013 to 2016. 2016. http://www.statista.com/statistics/237505/global-revenue-from-smartphonessince-2008/. Accessed 8 Aug 2016

2. Pew Research Center. Americans' views on mobile etiquette. 2015. http:// www.pewinternet.org/2015/08/26/americans-views-on-mobile-etiquette/. Accessed 8 Aug 2016

3. Pew Research Center. U.S. smartphone use in 2015. 2015. http://www. pewinternet.org/2015/04/01/us-smartphone-use-in-2015/. Accessed 8 Aug 2016.

4. AAA Foundation for Traffic Safety. 2014 Traffic Safety Culture Index. 2015. https://www.aaafoundation.org/sites/default/files/2014TSClreport.pdf. Accessed 2 Jan 2016.

5. Bianchi A, Phillips JG. Psychological predictors of problem mobile phone use. Cyberpsychol Behav. 2005;8(1):39-51.

6. Chen $\mathrm{Q}$, Yan Z. New evidence of impacts of cell phone use on driving performance: a review. Int J Cyber Behav Psychol Learn. 2013:3(3):46-61.

7. Collet C, Guillot A, Petit C. Phoning while driving II: a review of driving conditions influence. Ergonomics. 2010;53(5):602-16.

8. Collet C, Guillot A, Petit C. Phoning while driving I: a review of epidemiological, psychological, behavioural and physiological studies. Ergonomics. 2010;53(5):589-601. 
9. McCartt A. Cell phones and driving: review of research. Traffic Inj Prev. 2006;7(2):89-106.

10. National Highway Traffic Safety Administration: Traffic safety facts: driver electronic device use in 2014. 2015. www-nrd.nhtsa.dot.gov/Pubs/812197. pdf. Accessed 2 Jan 2016.

11. Overton T. Distracted driving: prevalence, problems, and prevention. Int J Inj Control Saf Promot. 2015;22(3):187-92.

12. Wilson FA, Stimpson JP. Trends in fatalities from distracted driving in the United States, 1999 to 2008. Am J Public Health. 2010;100(11):2213-9.

13. Atchley P, Hadlock C, Lane S. Stuck in the 70s: the role of social norms in distracted driving. Accid Anal Prev. 2012;48:279-84.

14. National Highway Traffic Safety Administration. Blueprint for ending distracted driving. 2012. ftp://nhtsa.gov/CPSCreative/blueprint/CA/brochure/ 8747-811629-060612-v4-FPO.pdf. Accessed 8 Aug 2016.

15. Insurance Institute for Highway Safety. Distracted driving. 2016. http://www. iihs.org/iihs/topics/laws/cellphonelaws?topicName=distracted-driving. Accessed 8 Aug 2016.

16. Cheng $C$. The effect of cell phone bans on driver behavior: accidents and casualties. Department of Economics Texas A\&M University. 2012. http:// econweb.tamu.edu/common/files/papers/JMPaper_Cheng.pdf. Accessed 2 Jan 2016.

17. Foss RD, Goodwin AH, McCartt AT, Hellinga LA. Short-term effects of a teenage driver cell phone restriction. Accid Anal Prev. 2009;41(3):419-24.

18. Goodwin AH, O'Brien NP, Foss RD. Effect of North Carolina's restriction on teenage driver cell phone use two years after implementation. Accid Anal Prev. 2012;48:363-7.

19. McCartt AT, Braver ER, Geary LL. Drivers' use of hand-held cell phones before and after New York State's cell phone law. Prev Med. 2003;36(5):629-35.

20. McCartt AT, Geary LL. Longer term effects of New York State's law on drivers' hand-held cell phone use. Inj Prev. 2004;10(1):11-5.

21. McCartt AT, Hellinga LA. Longer-term effects of Washington, DC, law on drivers' hand-held cell phone use. Traffic Inj Prev. 2007;8(2):199-204.

22. McCartt AT, Hellinga LA, Strouse LM, Farmer CM. Long-term effects of handheld cell phone laws on driver hand-held cell phone use. Traffic Inj Prev. 2010;11(2):133-41.

23. Pew Research Center. Cell phone acitivities 2013. 2013. http://www. pewinternet.org/2013/09/19/cell-phone-activities-2013/. Accessed 8 Mar 2014.

24. Tison J, Chaudhary NK, Cosgrove L. National phone survey on distracted driving attitudes and behaviors. 2012. http://ntl.bts.gov/lib/45000/45700/ 45720/811555.pdf. Accessed 12 Dec 2013.

25. Rhodes N, Pivik K. Age and gender differences in risky driving: the roles of positive affect and risk perception. Accid Anal Prev. 2011;43(3):923-31.

26. Zhang W, Gkritza K, Keren N, Nambisan S. Age and gender differences in conviction and crash occurrence subsequent to being directed to lowa's driver improvement program. J Saf Res. 2011;42(5):359-65.

27. Romano $E_{\text {, Voas }}$, Tippetts $S$. Stop sign violations: the role of race and ethnicity on fatal crashes. J Saf Res. 2006;37(1):1-7.

28. Romano E, Tippetts S, Fell J, Eichelberger A, Grosz M, Wiliszowski C. Traffic citation rates among drivers of different residency status in the United States. Accid Anal Prev. 2013;51:215-21.

29. Rakauskas ME, Ward NJ, Gerberich SG. Identification of differences between rural and urban safety cultures. Accid Anal Prev. 2009;41(5):931-7.

30. Thompson JP, Baldock MR, Mathias JL, Wundersitz LN. An examination of the environmental, driver and vehicle factors associated with the serious and fatal crashes of older rural drivers. Accid Anal Prev. 2013;50:768-75.

31. Pickrell TM. Driver electronic device use observation protocol. 2010. https:// crashstats.nhtsa.dot.gov/Api/Public/NiewPublication/811361. Accessed 8 Aug 2016.

32. Handsfreeinfo. Index: cell phone laws, legislation by state. 2016. http:// handsfreeinfo.com/index-cell-phone-laws-legislation-by-state/. Accessed 2 Jan 2013

33. Govenors Highway Safety Association. Distracted driving laws. 2016. http:// www.ghsa.org/html/stateinfo/laws/cellphone_laws.html. Accessed 8 Aug 2016.

34. Federal Communication Commission. Local telephone competition reports. 2016. https://www.fcc.gov/general/local-telephone-competition-reports. Accessed 13 Mar 2016

35. United States Census Bureau. Population estimates: state totals vintage 2014. 2016. https://www.census.gov/data/datasets/2016/demo/popest/statetotal.html. Accessed 10 Mar 2016.

36. Woodruff RS. A simple method for approximating the variance of a complicated estimate. J Am Stat Assoc. 1971;66(334):411-4.
37. Özkan T, Lajunen T. What causes the differences in driving between young men and women? The effects of gender roles and sex on young drivers' driving behaviour and self-assessment of skills. Transp Res Part F Traffic Psychol Behav. 2006;9(4):269-77.

38. Yagil D. Gender and age-related differences in attitudes toward traffic laws and traffic violations. Transp Res Part F Traffic Psychol Behav. 1998;1(2):123-35.

39. Yagil D. Instrumental and normative motives for compliance with traffic laws among young and older drivers. Accid Anal Prev. 1998;30(4):417-24.

40. Cosgrove L, Chaudhary N, Reagan I. Four high-visibility enforcement demonstration waves in Connecticut and New York reduce hand-held phone use. In. National Highway Traffic Safety Administration. 2011. https:// www.nhtsa.gov/sites/nhtsa.dot.gov/files/811845_hve_demonstration_ waves in cn ny tsf-rn-july2011.pdf. Accessed 10 May 2012.

41. National Highway Traffic Safety Administration. Distracted driving highvisibility enforcment demonstrations in California and Delaware. 2015. https://www.nhtsa.gov/sites/nhtsa.dot.gov/files/811993distracteddrivinghighvisibilityenforcement_ca-de-tt.pdf. Accessed 8 Aug 2016.

42. Shinar D, Drory A. Sign registration in daytime and nighttime driving. Hum Factors. 1983;25(1):117-22.

43. Lenné MG, Triggs TJ, Redman JR. Time of day variations in driving performance. Accid Anal Prev. 1997;29(4):431-7.

44. Rudisill TM, Zhu M. Who actually received celll phone use while driving citations and how much are these laws enforced among states? A descriptive, cross-sectional study. BMJ Open. 2016;6(6):e011381.

45. Governors Highway Safety Association: Distracted driving: survey of the states. 2013. http://www.ghsa.org/resources/2013distracted. Accessed 8 Aug 2016

\section{Submit your next manuscript to BioMed Central and we will help you at every step:}

- We accept pre-submission inquiries

- Our selector tool helps you to find the most relevant journal

- We provide round the clock customer support

- Convenient online submission

- Thorough peer review

- Inclusion in PubMed and all major indexing services

- Maximum visibility for your research

Submit your manuscript at www.biomedcentral.com/submit

) Biomed Central 